\title{
The Induction of Callus in Four Diverse Black Soybeans (Glycine soja Sieb. \& Zucc) with Various Combinations of Cytokinins and 2,4-Dichlorophenoxyacetinic Acid
}

\author{
Atra Romeida ${ }^{1}$, Hesti Pujiwati ${ }^{1}$, Supanjani ${ }^{1}$, Fahrurrozi $^{1}$, Marlin $^{1}$, Reny Herawati ${ }^{1}$ \\ ${ }^{1}$ Department of Crop Production, Faculty of Agriculture, The University of Bengkulu, \\ W.R.Supratman, st. Kandang Limun, Bengkulu, 38371. \\ *Corresponding author. Email: atraromeida@unib.ac.id
}

\begin{abstract}
The black soybean (Glycine soya Sieb. \& Zucc) is a species of legume native of East Asia, widely grown for its edible bean, which has numerous uses. Furthermore, it is used as a raw material in the soy sauce industry, and its protein and antioxidant content is preferred to yellow soybeans. This study was conducted to evaluate the in vitro callus growth pattern of four varieties of black soybean grown in various combinations of cytokinins and 2,4-dichlorophenoxyacetic acid (2,4-D), and was performed at the Agronomy Laboratory, Faculty of Agriculture, the University of Bengkulu. A completely factorial randomized design (RAL) with 10 replications was used in this experiment. The first factor was four varieties of black soybeans, namely Detam$1,2,3$, and 4. Similarly, the second factor was the type of cytokinin, namely $\mathrm{K} 0=0$ (control / without plant growth regulators), $\mathrm{K} 1=2 \mathrm{mg} \cdot \mathrm{L}^{-1} \mathrm{BAP}+0.5 \mathrm{mg} \cdot \mathrm{L}^{-1} 2,4-\mathrm{D}$, and $\mathrm{K} 2=2 \mathrm{mg} . \mathrm{L}^{-1}$ Kinetin $+0,5 \mathrm{mg} \cdot \mathrm{L}^{-1}$ 2,4-D. The mature cotyledon explants were cultured on Murashige and Skoog (MS) Medium. The results showed that Detam 2, 3 and 4 black soybean varieties grown on MS $+2 \mathrm{mg} \cdot \mathrm{L}^{-1} \mathrm{BAP}+0.5 \mathrm{mg}$. $\mathrm{L}^{-1} 2,4-\mathrm{D}$ medium produced more friable callus with clear green-yellow color as compared to those grown on MS $+2 \mathrm{mg}$.. $\mathrm{L}^{-1}$ Kinetin $+0.5 \mathrm{mg} . \mathrm{L}^{-1} 2,4-\mathrm{D}$. The greatest compact callus with yellow-green color were formed by Detam 1 variety planted on MS medium $+2 \mathrm{mg} \cdot \mathrm{L}^{-1}$ Kinetin $+0.5 \mathrm{mg} \cdot \mathrm{L}^{-1} 2,4-\mathrm{D}$. The greatest embryogenic callus production $(100 \%)$, the heaviest callus fresh weight $(1.53 \mathrm{~g})$ and the greatest fresh culture yield $(1.58 \mathrm{~g})$ of yellow-green callus with friable texture were produced by Detam 3 variety grown on MS + medium $2 \mathrm{mg}$. $\mathrm{L}^{-1}$ $\mathrm{BAP}+0.5 \mathrm{mg} \cdot \mathrm{L}^{-1} 2,4-\mathrm{D}$.
\end{abstract}

Keywords: Black Soybean, In vitro, Plant Growth Regulator, Embryogenesis, Glycine soja

\section{INTRODUCTION}

The black soybean (Glycine soja Sieb. \& Zucc) is a species of legume native of East Asia, widely grown for its edible bean, which has numerous uses, and it is also an important food crop in Indonesia. Furthermore, its advantages compared to yellow soybeans is that they contain high levels of antioxidants in the form of anthocyanins and isoplavones, which are very useful in increasing serum insulin production in the pancreas. Therefore, it is used as a nutraceutical for people with diabetes mellitus [1]. Each $130 \mathrm{~g}$ of black soybean seeds contains $6 \mathrm{~g}$ fat, $30 \mathrm{mg}$ sodium, $8 \mathrm{~g}$ carbon, $7 \mathrm{~g}$ fiber, $1 \mathrm{~g}$ sugar and $11 \mathrm{~g}$ protein [2]. Similarly, its seeds also contain substances that are useful and needed by humans, including protein $(35 \%)$, carbohydrates $(35 \%)$, fat $(15 \%)$, water $(13 \%)$ [3]

The black soybeans are used in the production of soymilk, tofu, soy sauce, soy oil, natto, tempeh, texturized soy protein, soy flour, soy protein isolate, soy protein concentrate, black soya hull extract (anthocyanin), etc. Nowadays, the trading based foods rises tremendously because of the increasing consumers awareness as a nutritious, healthy and functional food ingredient.

The superior black soybean varieties released by the Ministry of Agriculture of the Republic of Indonesia were Detam 1, 2, 3, 4, and Malika. Furthermore, Detam-1 variety was obtained by crossing the introduced line 9837 with Kawi, which has a high protein content of about $35.4 \%$, a potential yield of 2.86 tons.ha $^{-1}$. Detam-1 has big seed size, with 100 grain weight of 14.8 grams. This soybean variety is commercially developed by a seed and food industry as a raw material for making soy sauce [4].

The Detam 2 variety was obtained by crossing lines 9837 with Willis selection. The superiority of this variety has a high yield potential of $2.96 \mathrm{t} / \mathrm{ha}$, with a protein 
content of $45.6 \%$ and $14.8 \%$ dry weight of fat. This variety is resistant to pod suckers but sensitive to armyworms. The Detam 3 variety was obtained from crossing between the W9837 lines and the Cikuray variety selection. The potential yield of this variety is high, reaching about 3.15 t/ha with seed size of $11.8 \mathrm{~g} / 100$ seeds and moderately drought tolerant. Meanwhile, the Detam 4 variety was selected from a cross between W9837 line and 100H-236 line with a potential seed yield of $2.89 \mathrm{t} / \mathrm{ha}, 11 \mathrm{~g} / 100$ seeds size, drought tolerant in the reproductive phase, moderately resistant to pod-sucking pests and resistant to leaf rust disease [5] and [6].

According to Purwantoro [7] the main causes of low soybean production is the limited availability of superior seeds. The use of superior seeds can increase harvest success to about $60 \%$ [8]. Efforts have been made to accelerate the supply of black soybean seeds through plant tissue culture techniques [9]. Furthermore, the soybean somatic embryos can be stimulated by an increase to the overexpression of $35 \mathrm{~S}$ : gGmAGL15 protein in callus tissue derived from the seeds. The expression is the same with the Arabidobsis thaliana plant [10]. The regeneration of the Pisum sativum callus occurred 5 months after planting, and most of the roots of adventitious shoots were produced in $1 / 2$ MS medium addition with $1.5 \%$ sucrose, $0.1 \mathrm{mg} . \mathrm{L}^{-1} \mathrm{NAA}$ and $0.5 \mathrm{mg} . \mathrm{L}^{-}$ ${ }^{1}$ kinetin [11].

Base on [12], it was stated that addition of cytokinins and auxins mixed in culture medium can stimulate cell division and morphogenesis. Auxin 2,4-D is a growth inhibitor that plays a role in loosening the cell wall by releasing the hydrogen bonds in the cell wall. Acording to [13], the concentration of $0.5 \mathrm{mg} . \mathrm{L}^{-1} \quad 2,4-\mathrm{D}$ is best suited for callus fresh weight gain. The use of soybean shoot tip explants on MS medium + $3.0 \mathrm{mg} \cdot \mathrm{L}^{-1}$ 2,4-D + 1.0 mg. $\mathrm{L}^{-1}$ BAP resulted in $76.3 \%$ of callus. Somatic embryo formation from callus on shoot tip explants was produced on BS-6 medium. Most callus (88.8\%) was produced in soybean sprouts cotyledon hook explants, and callus development from shoot tips formed embryos (79.4\%), Proportion of formed embryo originating from cotyledon hook callus $(76.3 \%)$ were produced in MS medium with the addition of $2.5 \mathrm{mg} . \mathrm{L}^{-1} \mathrm{BAP}+1.0 \mathrm{mg} . \mathrm{L}^{-1} \mathrm{NAA}$. The longest shoots $(5.32 \mathrm{~cm})$ was produced on BS-6 media [14].

According to the results of the research conducted by Soto et al. [15], a high concentration of BAP decreased the number of shoots formed and increased abnormal shoots. The use of MS medium $+1.5 \mathrm{mg}$. $\mathrm{L}^{-1}$ BAP resulted in the highest shoot regeneration compared to the concentrations of $0.5-3 \mathrm{mg} . \mathrm{L}^{-1}$ ) in an in vitro culture of soybean varieties Cuban Incasoy-36 on MSB5 media. Similarly, the concentration of $1.0 \mathrm{mg} . \mathrm{L}^{-1}$ BAP gave the best results compared to other concentrations $\left(2.0 \mathrm{mg} . \mathrm{L}^{-1}\right)$ for an in vitro shoot formation on culture of NARC-4 and NARC-7 cultivars [16, 17]. BAP concentrations higher than $5 \mathrm{ppm}$ lead to abnormal growth and a decrease in the amount of plantlet regeneration [18]. The results of an experiment by Suminar et al. [8] demonstrated that the use of $1.5 \mathrm{mg} / 1 \mathrm{BAP}$ increased the number of leaves and the number of shoots formed on soybean explants.

This study aims to evaluate the in vitro callus growth pattern of four black soybean varieties grown in different combinations of cytokinins and 2,4dichlorophenoxyacetic acid (2,4-D).

\section{MATERIALS AND METHODS}

\subsection{Time and place}

In vitro experiment was the first stage experiment to produce embryogenic callus which will be used to test soybean resistance to water stress. This research was conducted at the Plant Tissue Culture Laboratory, Faculty of Agriculture, the University of Bengkulu.

\subsection{Plant Material and Culture Condition}

\section{Explant Sterilization}

The sterilization was carried out on several stages. First, black soybean seed explants were soaked in $50 \%$ detergent solution for 5 minutes and washed in running water, then immersed in $2 \%$ Agrept $+2 \%$ Benlate solution for 2 hours then rinsed with sterile water. Furthermore, the explants were immersed in $20 \%$ sodium hypocloride solution for 20 minutes, then rinsed three times with sterile water. The rinsed activity was carried out in a Laminar Airflow Cabinet. Finally, peeled and soaked soybean seeds in sterile water + Bethadine.

\section{Medium Preparation.}

The basic medium used in this experiment was Murashige and Skoog MS with the addition of $2 \%$ activated charcoal, 2 mg. $\mathrm{L}^{-1}$ Calcium Pantothenate; 30 g.L $\mathrm{L}^{-1}$ sucrose and $6 \mathrm{~g} \mathrm{~L}^{-1}$ Agar. The plant growth regulators used for treatment were 2,4Dichloropenoxyacetic acid (2,4-D), 6-Benzylamino purine (BAP), 6-Furfurylaminopurine (Kinetin). The concentration of growth regulators was applied according to the respective treatment. The $\mathrm{pH}$ of the in vitro growing media was adjusted to $\mathrm{pH}$ 5.8. The volume of planted media was $20 \mathrm{ml} / \mathrm{jar}$. The Jars filled with planting media were tightly closed, then sterilized using an autoclave at a temperature of $121^{\circ} \mathrm{C}$ with a pressure of 15 psi for 20 minutes. The sterilized media were incubated at room temperature for 1 week before planting.

\section{Culture Condition}

The sterile explant was planted in the MS medium under the Laminar Air Flow Cabinet. The mature of soybean seeds are peeled, cut into half, and the embryos attached to the seeds are removed. Furthermore, the sterile cotyledon are planted in the treatment medium 2 pieces of seed per jar. The jars containing cotyledon explants were covered with a transparent plastic. As a result, the culture jar were kept in the culture room with temperature set at $20^{\circ} \mathrm{C} \pm 4^{\circ} \mathrm{C}$, the light from the fluorescent lamp was 1000 lux, with the light : dark 
periode of 16: 8 hours per day and the room humidity was $\pm 70 \%$.

\subsection{Experimental Design and Data Analysis}

The experiment was arranged factorially under a Completely Randomized Design (CRD) with 10 replications. The first factor was four varieties of black soybeans, namely Detam-1, Detam-2, Detam-3, Detam4. The second factor was the type of cytokines, namely $\mathrm{K} 0=0$ (control $/$ without growth regulators), $\mathrm{K} 1=2$ $\mathrm{mg} \cdot \mathrm{L}^{-1} \mathrm{BAP}+0.5 \mathrm{mg} \cdot \mathrm{L}^{-1} 2,4-\mathrm{D}$, and $\mathrm{K} 2=2 \mathrm{mg} . \mathrm{L}^{-1}$ Kinetin $+0.5 \mathrm{mg} \cdot \mathrm{L}^{-1} 2,4-\mathrm{D}$.

The observation of explant growth was conducted to obtain quantitative and qualitative data. The quantitative data includes callus diameter, callus fresh weight, and total fresh weight. The qualitative data includes callus color observed using the Muncell Color Chart for cultured tissue and callus texture with criteria of friable callus or compact callus). Furthermore, the quantitative data were analyzed using Covariant Analysis using the $\mathrm{F}$ test of 5\% level. For the optimum concentration of PGR, polynomial and orthogonal tests was used. In order to obtain the best variety and the best media composition, the 5\% level of Least Significance Different (LSD) Test was used. The results of the microscopic analysis are displayed in the form of photographs.

\section{RESULTS AND DISCUSSION}

\subsection{Embryogenic callus induction}

Not all experimental units were contaminated with bacterials and fungi. In general, sterilization technique stages was standardized and can be used for sterilization of soy mature cotyledon explants. Mature cotyledon explants of 4 soybean varieties grown on MS medium with the addition of growth regulators by in vitro grew and developed into callus by $75 \%$, while $4.2 \%$ of live explants did not formed callus; and $20.8 \%$ of explants increased in volume but little or no callus is formed.

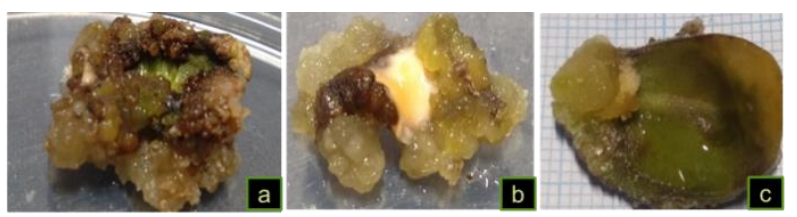

Figure 1. The Callus was formed from mature black Soy cotyledon at 10 WAP. a). friable callus with globular stage was reported in $2 \mathrm{ml} \mathrm{L}^{-1}$ kinetin $\left.+0.5 \mathrm{ml} \cdot \mathrm{L}^{-1} 2,4-\mathrm{D}, \mathrm{b}\right)$. embryogenic callus with globular and heart phase was reported in $2 \mathrm{ml}$ $\mathrm{L}^{-1} \mathrm{BAP}+0.5 \mathrm{ml} \cdot \mathrm{L}^{-1} 2,4-\mathrm{D}$. c). compact callus was reported in MS medium without plant growth regulator.

An embryogenic callus with friable characteristics, yellow or green-yellow colour, was produced on MS media with $2 \mathrm{ml} \cdot \mathrm{L}^{-1} \mathrm{BAP}+0.5 \mathrm{ml} \cdot \mathrm{L}^{-1} 2,4-\mathrm{D}$ and $2 \mathrm{ml} \mathrm{L} \mathrm{L}^{-1}$ kinetin $+0.5 \mathrm{ml} . \mathrm{L}^{-1}$ 2,4-D addition. Furthermore, the callus evolved into a globular and a heart phase, which were the main features of plant development through somatic embryogenesis pathways on the plant tissue culture. (Figure 1.)

The dominant callus colours identified were $60 \%$ Yellow (Y), 12\% green-yellow (YR), and 28\% GY yellow-green $(\mathrm{GY})$. The callus texture form was $86 \%$ friable and $14 \%$ compact. The friable callus was formed in MS medium with the addition of a growth regulator 2 mg. $\mathrm{L}^{-1}$ BAP + $0.5 \mathrm{mg} \cdot \mathrm{L}^{-1} 2,4-\mathrm{D}$, and $2 \mathrm{mg} . \mathrm{L}^{-1}$ Kinetin + $0.5 \mathrm{mg}$. $\mathrm{L}^{-1} 2,4-\mathrm{D}$. The compact callus was formed on soybean explants without growth regulators (control). The treatment of $2 \mathrm{mg} . \mathrm{L}^{-1} \mathrm{BAP}+0.5 \mathrm{mg} . \mathrm{L}^{-1} 2,4-\mathrm{D}$ produced a large quantity of callus, as much as $56 \%$, on all explants of black soybean varieties. The treatment of 2 mg.L-1 Kinetin $+0.5 \mathrm{mg} \cdot \mathrm{L}^{-1} 2,4-\mathrm{D}$. produced a large quantity of callus only $34 \%$; while $66 \%$ the quantity of callus ranges slightly to moderate. Most of the explant without plant growth regulator $(78 \%)$ only grew in volume but do not formed callus, and only $22 \%$ explant formed callus with little criteria.

Callus is an unorganized cell mass. The embryogenic callus has a friable structure, nodular and is yellow-white [19]. According to Andrianto [20], embryogenic callus initiation occurs as a response to stress due to the relatively high auxin concentrations.

Base on the results of Manurung et al. [21], Gepak Kuning and Grobogan were responsive Soybean varieties to embryogenic callus growth with growth percentage of about $100 \%$. The callus size induced by the Grobogan variety explants was greater than that of the Gepak Kuning variety. Generally, the resulting callus was yellow-white with a friable texture with the highest fresh callus weight $13 \mathrm{~g}$ ) obtained on MS medium supported with 2,4-D + 1,5 mg.L L $^{-1}$ BAP.

\subsection{Analysis of variance}

The variance analysis showed that the research data has high variability, and the coefficient of variability for all tested observed variables ranges between 54.04-211.9\%. Therefore, the transformations were carried out using $\sqrt{ }(\mathrm{x}+1)$. After being transformed, the coefficient of variation decreased to $15.65-24.15 \%$. The analysis of variance of observed variables were presented in Table 1 .

The resulted of the $\mathrm{F}$ test at a level of $5 \%$ showed that there was an interaction between black soybean varieties and growth regulators with regard to the callus diameter, callus fresh weight and total final weight. The only factor of black soybean varieties only affects the callus diameter and final total weight. Meanwhile, the treatment of growth regulators also affected all tested variables, namely callus diameter, callus fresh weight and total final weight. 
Table 1. Analysis of variance of soybean cotyledon explant growth: callus diameter, callus fresh weight, total fresh weight following culture at 10 weeks after planting (WAP)

\begin{tabular}{|c|c|c|c|c|c|c|c|c|}
\hline \multirow[t]{2}{*}{ Growth variable } & \multicolumn{6}{|c|}{ F-count } & \multirow[t]{2}{*}{ CV (\%) } & \multirow{2}{*}{$\begin{array}{l}\mathrm{CV}(\%) \\
\sqrt{x+1}\end{array}$} \\
\hline & Variety & $\mathrm{P}$ & PGR & $P$ & Interaction & $\mathrm{P}$ & & \\
\hline Callus Diameter & $3.92 *$ & 0.0400 & $4.22 *$ & 0.0203 & $0.82 \mathrm{~ns}$ & 0.5588 & 211.97 & 24.15 \\
\hline Callus Fresh Weight & $0.56 \mathrm{~ns}$ & 0.5783 & $66.25^{*}$ & 0.0000 & $2.79 *$ & 0.0205 & 54.04 & 15.63 \\
\hline Total Fresh Weight & $2.800 *$ & 0.0498 & $20.02 *$ & 0.0000 & $3.30 *$ & 0.0084 & 55.61 & 16.02 \\
\hline
\end{tabular}

Note : $\mathrm{CV}=$ Coefisien of variation

\subsection{The interaction Effect of black soybeans varieties and Plant Growth Regulator}

The interaction of 4 black soybean varieties with plant growth regulators on the callus diameter demonstrated quadratic shape curves. The diameter callus treated by MS medium $+2 \mathrm{mg} \cdot \mathrm{L}^{-1} \mathrm{BAP}+0.5$ mg. $\mathrm{L}^{-1}$ 2,4-D produced bigger callus than those treated by MS medium treatment $+2 \mathrm{mg} \cdot \mathrm{L}^{-1}$ kinetin $+0.5 \mathrm{mg}$. $\mathrm{L}^{-1} 2,4-\mathrm{D}$.

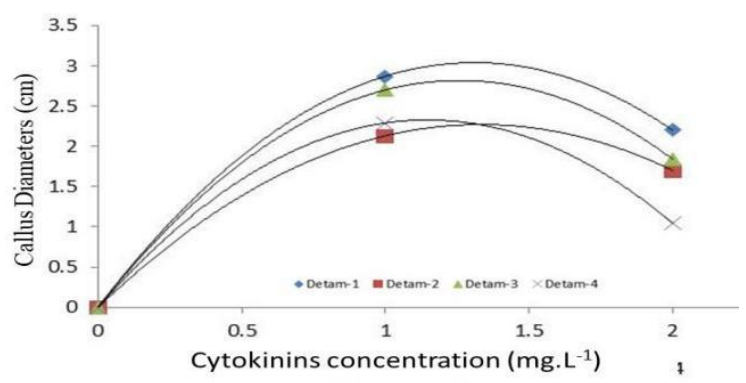

Figure 2. The interaction of 4 black soybean varieties with growth regulators on callus diameter

In this experiment, under control condition, explant grow very slowly, callus diameter was formed only $0.5 \mathrm{~cm}$; and most of explant enlarged with the additon of cytokinin (Figure 2).

All the explants of 4 varieties grown on the treatment medium produced a quadratic curve with the addition of BAP up to $2 \mathrm{mg} . \mathrm{L}^{-1}$. The treatment media $\mathrm{MS}+2 \mathrm{mg} \cdot \mathrm{L}^{-1} \mathrm{BAP}+0.5 \mathrm{mg} \cdot \mathrm{L}^{-1} 2,4-\mathrm{D}$ produced greater callus than MS medium treatment $+2 \mathrm{mg} \cdot \mathrm{L}^{-1}$ kinetin $+0.5 \mathrm{mg} . \mathrm{L}^{-1} 2,4-\mathrm{D}$. The explant planted on MS medium without BAP or kinetin (Control) did not form callus until 10 weeks after planting. The interaction pattern of 4 black soybean varieties with growth regulators on callus fresh weight is shown in Figure 3.

The results of this study differs from those conducted by Chaa bani [22]. The combination of 2 ppm BAP and 10 ppm 2,4-D can increase callus fresh weight and dry weight of soybeans. There is a significant interaction between Cultivar and growth regulators $5 \mathrm{mg} \cdot \mathrm{L}^{-1}$ 2,4-D + $1 \mathrm{mg} . \mathrm{L}^{-1}$ on the increase in fresh weight of embryogenic callus soybean of Gepak Kuning variety. This study uses a lower BAP concentration combined with a high 2,4-D concentration of up to $10 \mathrm{ppm}$ compared with Chaa^bani's research

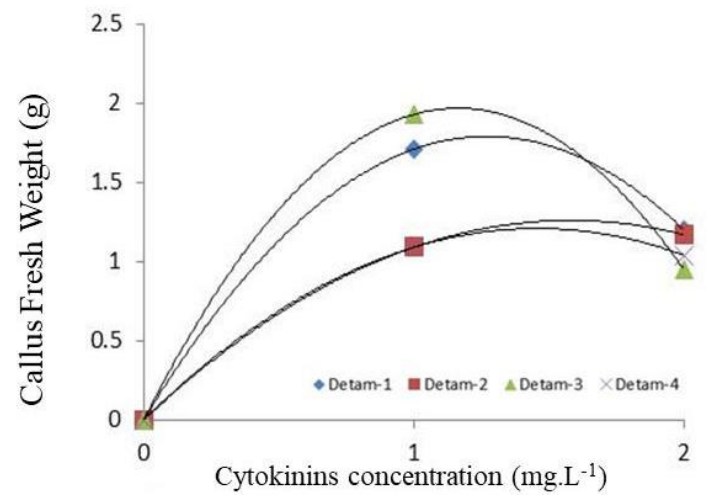

Figure 3. The interaction of 4 black soybean varieties with growth regulators on callus fresh weight.

Several information from the results showed that using the right combination of BAP and 2,4-D, in addition to the induce callus formation, can also increase phenolic compounds, which can accelerate callus browning. The results of the biochemical analysis showed that the highest total phenolic contents were obtained in callus cultured on MS medium supplemented with $2.0 \mathrm{mg} / \mathrm{L}$ 2,4-D and $1.0 \mathrm{mg} / \mathrm{L}$ BAP $(52-0.56 \mathrm{mg} \mathrm{GAE} / \mathrm{g} \mathrm{DM})$ and were significantly lower than those of intact leaves $(76-1.72 \mathrm{mg} \mathrm{GAE} / \mathrm{g}$ DM) [22].

The interaction pattern of 4 black soybean varieties with growth regulators on total fresh weight. There were 3 out of 4 varieties that were planted on the treatment medium to form a quadratic curve, namely Detam 2, 3 and 4 varieties. The optimum concentration was not attained on Detam 1, because the regression analysis formed a linear curve. The MS medium +2 mg. $\mathrm{L}^{-1}$ kinetin $+0.5 \mathrm{mg} \cdot \mathrm{L}^{-1}$ 2,4-D produced total fresh weight heavier than the treatment with MS media +2 
mg. $\mathrm{L}^{-1} \mathrm{BAP}+0.5 \mathrm{mg} . \mathrm{L}^{-1} 2,4-\mathrm{D}$ and control treatment or planting explants on MS medium without BAP or kinetin up to 10 weeks after planting. The heaviest total fresh weight was reported in Detam $3(1.58 \mathrm{~g})$ as compared to the Detam 1, Detam 2 and Detam 4 varieties (Figure 4).

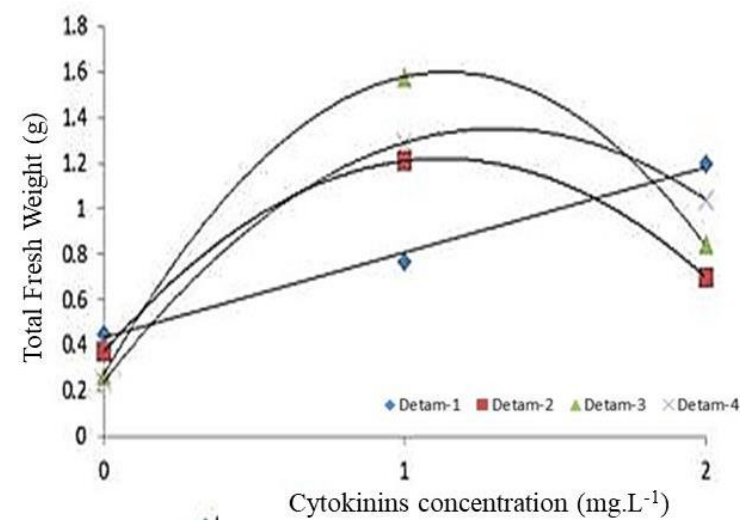

Figure 4. The interaction of 4 black soybean varieties with growth regulators on total fresh weight

Based on the quadratic curve, the highest total fresh weight of yield growth was estimated at 2.24 mg. $L^{-1}$ BAP +0.5 mg.L - $^{-1}$ 2,4-D at Detam 3 variety (1.58 $\mathrm{g})$, followed by Detam $4(1.29 \mathrm{~g})$. The maximum weight was produced at $2.27 \mathrm{mg} . \mathrm{L}^{-1} \mathrm{BAP}+0.5 \mathrm{mg} . \mathrm{L}^{-1}$ 2,4-D concentration. Detam 2 gave the total production fresh weight $(1.21 \mathrm{~g})$ at $2.56 \mathrm{mg} . \mathrm{L}^{-1} \mathrm{BAP}+0.5 \mathrm{mg} . \mathrm{L}^{-1}$ 2,4-D.

\section{CONCLUSION}

The results showed that Detam 2, 3 and 4 black soybean varieties grown on $\mathrm{MS}+2 \mathrm{mg} . \mathrm{L}^{-1} \mathrm{BAP}+0.5$ mg. $\mathrm{L}^{-1}$ 2,4-D medium produced more friable callus with a light green-yellow colour compared with those on $\mathrm{MS}+2 \mathrm{mg} . \mathrm{L}^{-1}$ Kinetin + $0.5 \mathrm{mg} . \mathrm{L}^{-1}$ 2,4-D and control. Furthermore, most embryogenic callus production $(75 \%)$, heaviest callus in fresh weight $(1.53$ $\mathrm{g})$ and the maximum fresh culture yield $(1.58 \mathrm{~g})$, as well as yellow-green callus with friable texture were produced by Detam 3 varieties grown on MS + medium 2 mg.L-1 BAP + 0.5 mg.L-1 2,4-D.

\section{ACKNOWLEDGMENT}

The authors express profound gratitude to the University of Bengkulu that funded this research through University of Bengkulu Leading Research of 2019 fiscal year with the contract number: 2180/UN30.15/LT/2019.

\section{REFERENCES}

[1] Mueller, 2012. Soy intake and risk of type 2 Diabetes mellitus in Chinese Singaporeans. Soy intake and risk of type 2 diabetes. Eur J nutr.; 51(8):1022-40.

[2] Miles, M.R., Frederick, R.D., Hartman, G.L. 2004. Soybean rust: Is the U.S. Soybean Crop At Risk? APS Net Plant Pathology Online. USDA

[3] Suprapto. 2000. Kedelai dan Cara Bercocok Tanam. Puslitbangtan, Bogor.

[4] Gaibimei, 2018. Ultrasound Assisted Extraction of Oil from Soybean. International Journal of Current Microbiology and Applied Sciences. 7: 843-852

[5] [Balitkabi] 2015. Deskripsi Varietas Unggul Kedelai 1918-2014. Balai Penelitian Kacang-kacangan dan Umbi-umbian.. Malang. 89 Pages

[6] [Balitkabi]. 2016. Description of superior soybean varieties 1918-2016. Research center for various plants of nuts and tubers, Malang.

[7] Purwantoro. 2012. Percepatan Penyebaran Varietas Unggul Melalui Sistem Penangkaran Perbenihan Kedelai di Indonesia. Balai Penelitian Tanaman Aneka Kacang dan Umbi. Malang.

[8] Suminar, E. , Sumadi , S. Mubarok, T. Sunarto dan N. S. E. Rini. 2017. Percepatan Penyediaan Benih Sumber Kedelai Unggul Secara In Vitro. Jurnal Agrikultura, 28 (3): 126-135.

[9] Kumianjani, A.B.E., R.I. Damanikdan L.A.M. Siregar. 2015. Pengaruh Pemberian N 2,4-D Terhadap Pertumbuhan dan Metabolisme Kalus Kedelai Pada Kondisi Hipoksida Secara In Vitro. Jurnal Agroekoteknologi, 1(4):1673-1680

[10] Thakare, D., W. Tang, K. H and E. Perry. 2008. The MADS-Domain Transcriptional Regulator AGAMOUS-LIKE15 Promotes Somatic Embryo Development in Arabidopsis and Soybean. Plant Physiology, 146:1663-1672.

[11] El Sayed, H. A and El Sayed. 2011. Regeneration of callus and organogenesis from explants in Pisum sativum L. Using various basal medium cultures. Egypt. J. Exp. Biol. (Bot.), 7(1): 143 - 151.

[12] Khasanah, U. 2009. Pengaruh konsentrasi NAA dan Kinetin terhadap multiplikasi tunas pisang (Musa paradisiaca L. Cv. Raja Bulu) secara in vitro. Skripsi. Universitas Sebelas Maret. Surakarta 
[13] Fatmawati, A. 2008. Kajian Konsentrasi BAP dan 2,4-D Terhadap Induksi Kalus Terhadap Tanamaan Artemisia annua L. secara in vitro. Skripsi. Fakultas pertanian UNS. Surakarta

[14] Islam, N., T. Islam, M. M. Hossain, B. Bhattacharjee, M. M. Hossain and M. S. Islam. 2017.Embryogenic Callus Induction and Efficient Plant Regeneration in Three Varieties of Soybean (Glycine max). Plant Tissue Cult. \& Biotech. 27(1): 41-50.

[15] Soto, N., A. Ferreira,C. Delgado, and G. A. Enríquez.2013. In vitro regeneration of soybean plants of the CubanIncasoy-36 varietyBiotecnología Aplicada 2013;30:34-38

[16] Zia, M, ZF Rizvi, R Rehman and MF Chaudhary. 2010. Micropropagation of two Pakistan soybean (Glycine max L.) cultivars from cotyledonary nodes. J. Agr. R 8(2): 448-453.

[17] Huda, S. R.Islam, M.A. Bari, and M.Asaduzzaman. 2003. Shoot Differentiation from Cotyledon Derived Callusof Chickpea (Cicer arietinum L.). Plant Tissue Cult. 13(1) : 53-59.

[18] Pratama, A.P., and K. Zakiah. 2018. Pemberian konsentrasi Benzyle Amino Purine (BAP) DAN inokulan Bradyrhizobium japonicum terhadap pertumbuhan bintil akar tanaman Kedelai Hitam. Beranda. JAGROS. 3(1):31-38

[19] Yelnitis dan Komar, M. 2010. Pembentukan Kalus Remah dari Eksplan Daun Ramin (Gonystylus bancanus (Miq) Kurtz). Balai Besar Penelitian Bioteknologi dan Pemuliaan Tanaman Hutan.

[20] Indrianto, A. 2003. Kultur Jaringan Tumbuhan. Fak. Biologi UGM. Yogyakarta. 134 hal.

[21] Manurung, B. H., R. I. Damanik, E. S. Bayu. 2018. Kombinasi 2,4 D dan BAP untuk induksi kalus embriogenik beberapa varietas Kedelai (Glycine max (L.) Merrill) pada kondisi hipoksia secara in vitro. Jurnal Agroekoteknologi FP USU, 6(1):86-92.

[22] Chaa^bani, 2015 Chaa^bani, G., J. Tabart, C. Kevers, and J. Dommes, M.I. Khan, S. Zaoui, L. Chebchoub, M. Lachaa, and N. Karray-Bouraoui. 2015. Effects of 2,4-dichlorophenoxyacetic acid combined to 6Benzylaminopurine on callus induction, total phenolicand ascorbic acid production, and antioxidant activities in leaf tissue cultures of Crataegus azarolus L. var. aroniaActa Physiol Plant (2015) 37:16. DOI 10.1007/s11738-014-1769-4 